\title{
SOSIALISASI KEBERSIHAN SANITASI LINGKUNGAN DALAM RANGKA PENGURANGAN ANGKA STUNTING DI DESA JENGGALA KECAMATAN TANJUNG KABUPATEN LOMBOK UTARA
}

\author{
Socialization of Environmental Sanitation Cleanliness to Reduce Stunting \\ Numbers In Jenggala Village, North Lombok District
}

\author{
Ni Nyoman Kencanawati ${ }^{1 *}$, Eva Yunara ${ }^{2}$, dan Livia TN Pavita ${ }^{3}$ \\ ${ }^{1}$ Jurusan Teknik Sipil Unversitas Mataram, ${ }^{2}$ Program Studi Agribisnis Universitas Mataram, \\ ${ }^{3}$ Program Studi Ilmu Komunikasi Universitas Mataram \\ Jalan Majapahit Nomor 62 Kota Mataram Provinsi NTB \\ *Alamat korespondensi : kencanawati@unram.ac.id
}

(Tanggal Submission: 23 Mei 2020, Tanggal Accepted: 28 Agustus 2020)

\begin{abstract}
ABSTRAK
Sanitasi lingkungan yang buruk berdampak pada kesehatan masyarakat, salah satunya yaitu timbulnya gejala stunting pada anak. Stunting merupakan keterlambatan pertumbuhan pada anak. Stunting pada anak merupakan konsekuensi dari beberapa faktor yang salah satunya sering dikaitkan dengan masalah sanitasi dan lingkungan. Menurut Dinas Kesehatan NTB (2017) , Kabupaten Lombok Utara merupakan salah satu kabupaten dengan tingkat stunting yang tinggi di Provinsi Nusa Tenggara Barat dimana Desa Jenggala adalah salah satu desa yang terdapat para penderita stunting. Berdasarkan observasi di lapangan, Desa Jenggala tercatat memiliki permasalahan sanitasi lingkungan yang kurang baik dengan minimnya jumlah fasilitas sanitasi dan terdapat 38 anak mengalami stunting. Kegiatan pengabdian kepada masyarakat ini dilakukan dengan memberikan sosialisasi mengenai sanitasi hygiene dan perilaku hidup bersih dan sehat (PHBS) yang sangat dibutuhkan dalam rangka menekan angka stunting pada masyarakat Desa Jenggala Kecamatan Tanjung Kabupaten Lombok Utara. Metode kegiatan dibagi dalam beberapa tahapan yaitu tahap pertama adalah pengumpulan data primer (kondisi sanitasi) dan sekunder (data penderita stunting). Tahap kedua analisis data dan identifikasi masalah. Tahap terakhir adalah kegiatan sosialisasi dengan memberikan solusi berdasarkan hasil analisis data dan identifikasi masalah yang ada. Kegiatan sosilaisasi terbagi dalam dua sesi yaitu yang pertama penyuluhan dan diskusi dan yang kedua penguasaan materi dengan memberikan pertanyaan yang berkaitan dengan permasalahan. Sasaran sosialisasi yang utama adalah pada kelompok ibuibu PKK. . Kelompok berikutnya ditujukan pada anak-anak sekolah dasar yang menerima sosialisasi sekaligus praktek cara mencuci tangan yang benar. Hasil evaluasi menunjukkan sekitar $87 \%$ para lbu dapat menjawab pertanyaan dan diskusi yang diberikan. Hal menunjukkan kemampuan mereka dalam menyerap materi yang bagus. Dengan demikian diharapkan Ibu-ibu PKK mampu menyebarkan materi ke teman ataupun keluarga. Sebaliknya, hampir seluruh anak-anak sekolah peserta sosialisasi tidak mengetahui cara mencucui tangan yang benar. Namun, setelah sosialisasi sekitar $80 \%$ siswa dapat melakukannya dengan baik dan benar. Dengan meningkatkan kesadaran masyarakat Desa Jenggala terhadap kebersihan sanitasi lingkungan, diharapkan tingkat penderita stunting dapat menurun.
\end{abstract}

Kata kunci: sanitasi lingkungan, stunting, sosialisasi, Desa Jenggala 


\section{PENDAHULUAN}

Setiap individu memiliki kebutuhan mendasar salah satunya kesehatan. Namun demikian, seperti dinyatakan oleh Kementrian Kesehatan RI, 2020 bahwa kesehatan seringkali menjadi sumber dari berbagai permasalahan yang dialami manusia dan lingkungan sekitarnya. Selanjutnya, sesuai dengan teori kesehatan oleh Bloom yang menyatakan bahwa terdapat 4 faktor yang mempengaruhi derajat kesehatan yaitu: 1 ) gaya hidup, 2) lingkungan, 3) pelayanan kesehatan, dan 4) faktor genetik. Faktor gaya hidup dan lingkungan sangat erat kaitannya dengan tingkat sanitasi lingkungan yang diterapkan masyarakat (Fewtrell and Colford, 2005). Demikian halnya dengan tingkat kebersihan sanitasi lingkungan yang diterapkan suatu masyarakat akan berpengaruh terhadap tingkat kesehatan individu yang ada didalamnya, khususnya anak-anak yang rentan akan ancaman penyakit (Waluya, 2008).

Badan kesehatan dunia, WHO, telah membuktikan melalui penelitiannya di seluruh dunia dengan menghasilkan data bahwa tingginya angka kematian (mortalitas), angka kematian orang sakit (morbiditas) serta seringnya terjadi epidemi ditemukan di tempat-tempat yang kondisi hygiene dan sanitasi lingkungannya buruk, seperti banyak sampah menumpuk, lalat, nyamuk, dan kondisi air yang buruk (WHO, 2014). Sanitasi lingkungan adalah status kesehatan suatu lingkungan yang mencakup perumahan, pembuangan kotoran, penyediaan air bersih dan sebagainya (Notoadmojo, 2003). Hasil analisis sanitasi lingkungan di salah satu keluarahan di Jakarta menunjukkan bahwa balita dengan status gizi normal sebagian besar memiliki sanitasi lingkungan dengan kategori baik yaitu sebesar 100 $\%$. Balita dengan status gizi stunting sebagian besar memiliki sanitasi lingkungan dengan kategori baik yaitu sebesar $68,4 \%$, namun balita dengan status gizi stunting sebesar 31,6 \% memiliki sanitasi lingkungan dengan kategori tidak baik (Rahayu dan Darmawan, 2019). Hasil penelitian ini menyimpulkan bahwa ada hubungan yang signifikan antara sanitasi lingkungan dengan kejadian stunting pada balita. Hasil penelitian ini sejalan dengan penelitian Oktavia dalam Rahayu dan Darmawan, 2019, dan penelitian dari Vilcins, Sly, dan Jagals, 2018, yang menunjukkan bahwa ada hubungan yang signifikan antara balita yang memiliki sanitasi lingkungan tidak baik dengan kejadian stunting pada balita.

Saat ini stunting menjadi salah satu masalah yang harus segera ditangani oleh pemerintah Indonesia. Dimana stunting merupakan ancaman utama terhadap kualitas manusia Indonesia, juga ancaman terhadap kemampuan daya saing bangsa. Hal ini dikarenakan anak yang menderita stunting bukan hanya mengganggu pertumbuhan fisiknya saja, melainkan juga akan mengganggu perkembangan otaknya. Hal ini tentunya akan sangat berpengaruh terhadap kemampuan dan prestasi anak dalam pendidikan, produktivitas dan kreativitas anak di usia-usia produktif (UNICEF, 2012).

Pemerintah Indonesia saat ini melalui Gerakan Indonesia Emas mencoba untuk mengurangi angka stunting. Kabupaten Lombok Utara merupakan salah satu kabupaten dengan tingkat stunting yang tinggi di Provinsi Nusa Tenggara Barat yaitu 37,6\% (Dinas Kesehatan NTB, 2017). Disebutkan bahwa salah satu desa di Kabupaten Lombok Utara yang termasuk adalah Desa Jenggala, Kecamatan Tanjung. Sanitasi yang kurang baik dalam lingkungan masyarakat Desa Jenggala berakibat pada kesehatan masyarakat, dimana beberapa anak diantaranya mengalami stunting. Dengan demikian diperlukan suatu kegiatan yang bertujuan untuk meningkatkan kesadaran masyarakat Desa Jenggala akan pentingnya sanitasi yang baik dan benar melalui Sosialisasi Pola Hidup Bersih Dan Sehat. Kegiatan ini telah dilaksanakan dan hasilnya ditulis dalam jurnal ini. Kegiatan dilaksanakan dengan dua tahapan sosialisasi serta sasaran yang berbeda yaitu pada Ibu-ibu PKK dan anak-anak sekolah dasar. Kedua sasaran dipilih dengan latar belakang bahwa 
hubungan antara sanitasi dan hygiene keluarga serta tumbuh kembang balita dan anak sangat dipengaruhi oleh peran ibu dalam rumah tangga dan peran individu anak itu sendiri (Prastiti dan Sofyan, 2019).

\section{METODE KEGIATAN}

Kegiatan dilakukan di Desa Jenggala, Kecamatan Tanjung, Kabupaten Lombok Utara. Peta lokasi Desa Jenggala terlihat pada Gambar 1. Metode yang digunakan dalam kegiatan ini adalah pengumpulan data secara primer dan sekunder. Data primer terkait permasalahan sanitasi diperoleh melalui observasi pada lokasi. Beberapa visualisasi mengenai kondisi sanitasi di tangkap dengan bantuan kamera untuk selanjutnya dilakukan analisis gambaran kondisi sanitasi dan hygiene didaerah tersebut.

Data sekunder didapatkan dari lembaga terkait yaitu kantor desa, Dinas Kesehatan Daerah setempat dan Puskesmas. Data yang didapatkan berupa profil Desa Jenggala, jumlah penduduk, jumlah pemukiman, jumlah MCK keseluruhan, jumlah MCK yang sesuai dengan standar untuk penyandang stunting, jumlah anak secara keseluruhan, jumlah anak penderita stunting serta tingkat kecukupan gizi pada anak. Data sekunder ini selanjutnya digunakan untuk mengetahui perkembangan jumlah penderita sunting dan fasilitas MCK khusus disediakan untuk penderita stunting.

Berdasarkan data primer dan sekunder, selanjutnya dilakukan analisis identifikasi permasalahan yang ada meliputi:

1. Mengidentifikasi kondisi santitasi dan hygiene di Desa Jenggala.

2. Mengidentifikasi fasilitas MCK disetiap keluarga.

3. Mengidentifikasi perkembangan jumah penderita stunting.

4. Mengidentifikasi fasilitas MCK bagi penderita stunting.

Setelah permasalahan diidentifikasi, rancangan materi penyuluhan dan solusi-solusi dari permasalahan tersebut diatas dipersiapkan. Tahapan kegiatan dapat dilihat pada Gambar 2.

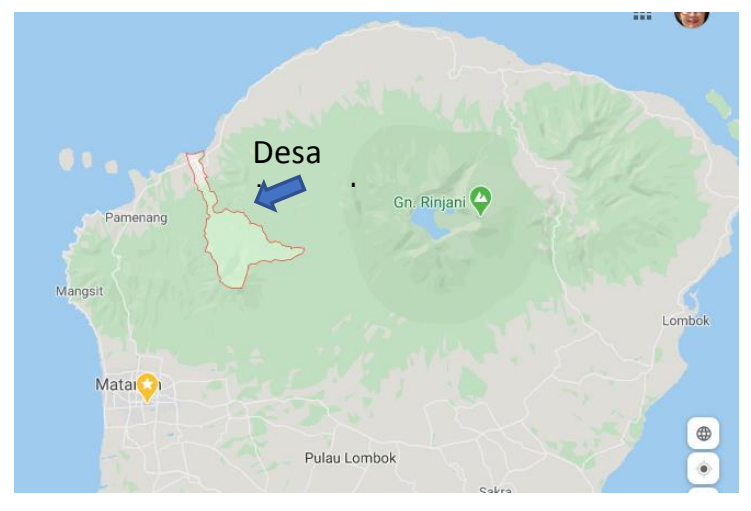

Gambar 1. Lokasi Desa Jenggala (Google Maps, 2020) 


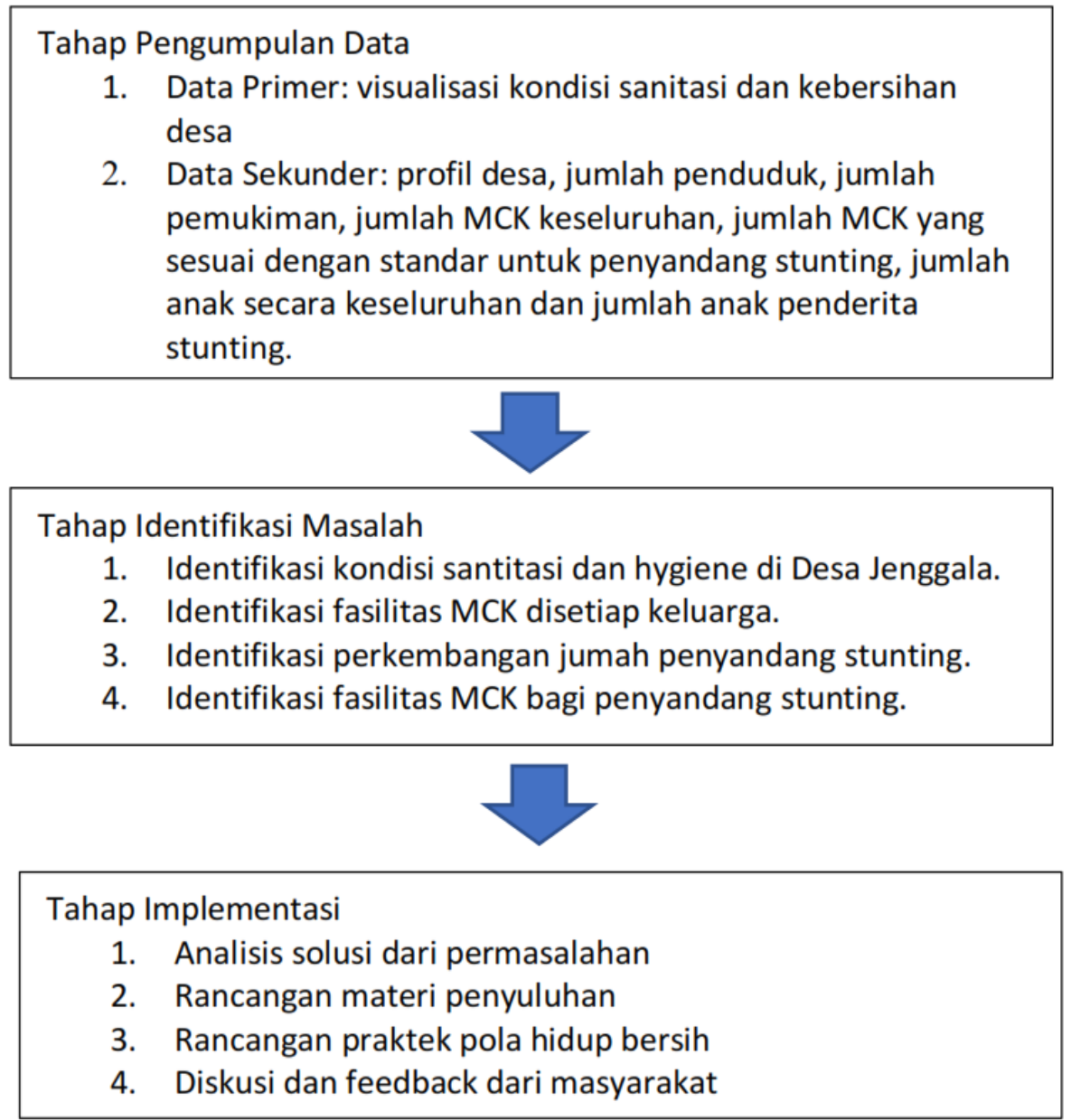

Gambar 2. Tahapan Pelaksanaan Kegiatan

\section{HASIL DAN PEMBAHASAN}

\section{Gambaran Umum Desa}

Desa Jenggala merupakan salah satu desa yang berada di Kecamatan Tanjung Kabupaten Lombok Utara. Desa ini terbagi menjadi 16 dusun dengan jumlah penduduk sebanyak 9.194 jiwa dimana 4.500 orang laki-laki dan 4.694 orang perempuan, dengan 2.251 jiwa berusia di bawah 17 tahun dan 1.184 berusia di atas 55 tahun yang tersebar di 16 dusun tersebut.

Wilayah desa Jenggala memiliki batasbatas sebagai berikut: 1) Sebelah utara berbatasan dengan Laut Jawa, 2) Sebelah selatan berbatasan dengan Desa Narmada, 3) Sebelah timur berbatasan dengan Desa Gondang, 4) Sebelah barat berbatasan dengan Desa Tanjung. Sarana dan prasaran yang tersedia di Desa Jenggala diantaranya yaitu : fasilitas kesehatan berupa puskesmas pembantu, poliklinik, apotik, posyandu, toko obat, dan rumah/kantor praktek dokter, dengan jumlah keseluruhan yaitu 15 unit; prasarana air bersih dengan jenis sumur pompa, sumur gali, hidran umum, penampung air hujan, tangki air bersih, embung, mata air dan bangunan pengolahan air; prasarana irigasi berupa saluran primer, saluran sekunder, saluran tersier, pintu sadap dan pintu pembagi air.

Desa Jenggala juga dilengkapi dengan lembaga kemasyarakatan desa yang bertujuan untuk mempermudah pelaksanaan pemerintahan desa. Terdapat pula kelompok ibu-ibu PKK dan kelompok remaja karang taruna.

\section{Keadaan dan Kualitas Sanitasi}


Secara umum di beberapa tempat di Desa Jenggala terdapat wilayah dengan sanitasi lingkungan yang kurang baik seperti yang terilihat pada Gambar 3. Beberapa kondisi yang menunjukkan sanitasi yang kurang baik adalah:

1. Tidak adanya bak sampah yang tersedia secara umum bagi masyarakat.

Dengan tidak adanya bak sampah umum, maka banyak sampah menumpuk di jalanan dan beberapa tempat lainnya

2. Tidak adanya tempat penampungan akhir sampah,

Dampaknya adalah sampah seringkali dibuang ke selokan

3. Terdapat genangan air selokan yang tidak terurus

Akibat pembuangan sampah ke selokan maka aliran air menjadi menjadi terhalang dan kondisinya sangat kotor karena tidak pernah dibersihkan

4. Tidak semua rumah memiliki fasilitas MCK Hal ini berpengaruh pada meningkatnya kebiasaan buang air sembarangan

5. Tidak ada fasilitas MCK dengan struktur yang sesuai untuk penderita stunting
Penderita stunting memiliki ukuran yang berbeda dari normal sehingga mereka kesulitan dalam melakukan proses buang air.

Berdasarkan hasil observasi, hal-hal tersebut diatas terjadi akibat kurangnya disiplin dan masih rendahnya kesadaran masyarakat untuk menjaga kebersihan lingkungan. Masih banyak dijumpai masyarakat yang membuang sampah sembarangan, membuang air besar sembarangan, dan prasarana sanimas yang tidak terurus. Menurut Ruel dan Arimond (2003) kebersihan yang buruk dan sanitasi merupakan indikator utama penyakit yang menyebabkan kekurangan gizi. Apabila sanitasi buruk, kemungkinan terserang penyakit dan prevalensi gizi buruk meningkat (Ningsih,2013). Sanitasi yang buruk meliputi, 1) masih banyaknya warga yang buang air besar sembarangan (BABS), 2) membuang sampah sembarangan, 3) tidak adanya pengelolaan pembuangan limbah rumah tangga seperti sabun, tinja, limbah dapur dan lainnya seperti halnya yang masih ditemui di Desa Jenggala. Khusus penyandang stunting seharusnya terdapat prasarana khusus MCK yang strukturnya disesuaikan dengan keadaan tubuh mereka.

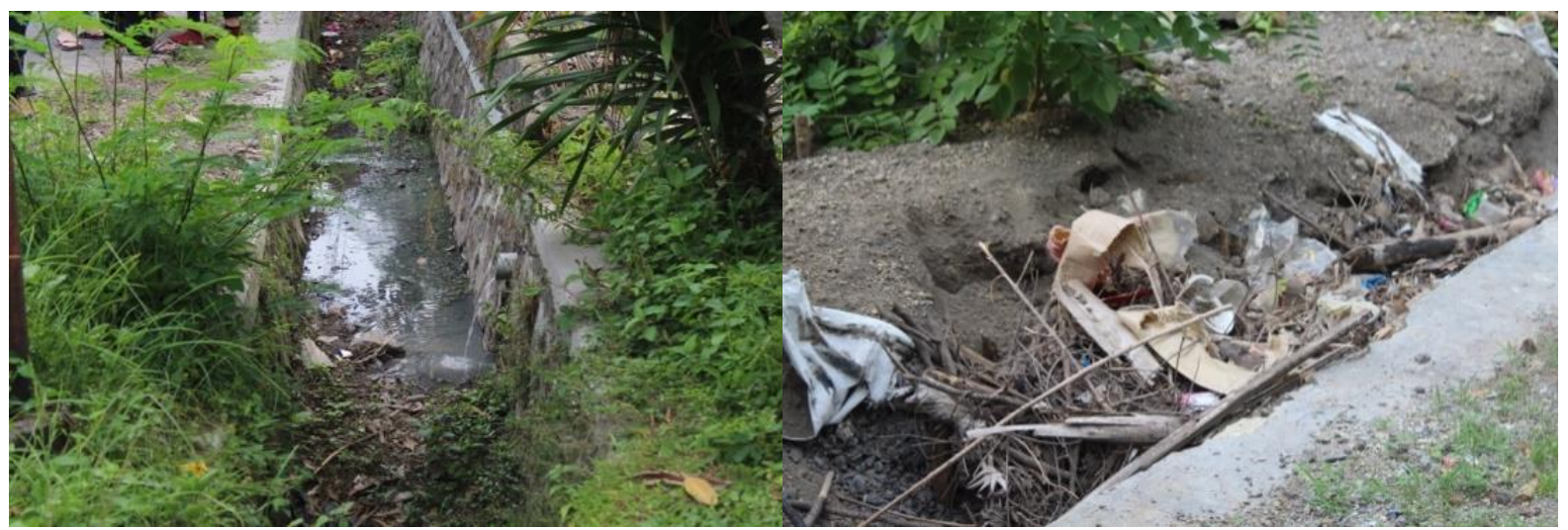

Gambar 3. Gambaran Keadaan dan Kondisi Sanitasi

\section{Kondisi Tumbuh Kembang Anak dan Penderita Stunting}

Data terakhir dari Puskesmas Kecamatan Tanjung (2019) menunjukkan jumlah anak-anak di Desa Jenggala adalah 193 anak. Dari total nilai tersebut, menunjukkan angka stunting sebanyak 38 anak dengan kategori gizi kurang, gizi lebih dan gizi buruk. Sedangkan 155 anak lainnya termasuk kategori gizi baik. Rincian data kondisi gizi anak ditampilkan pada Tabel 1. 
Berdasarkan pengamatan yang telah dilakukan dapat disimpulkan bahwa terdapat beberapa faktor yang menjadi penyebab masih terdapatnya kejadian stunting pada wilayah tersebut, diantaranya: 1) akses kesehatan bagi masyarakat yang berada jauh dari daerah perkotaan, 2) pengetahuan akan kesehatan dan kebersihan yang masih minim dikalangan anak dan orang tua, 3) kurangnya praktek sanitasi yang baik dalam lingkungan masyarakat, 4) masih banyak budaya membuang sampah sembarangan, 5) masih terdapat kebiasaan buang air besar sembarangan pada beberapa wilayah pesisir pantai, dan 6) kurangnya pengelolaan terhadap fasilitas sanitasi masyarakat.

Hubungan signifikan menunjukkan bahwa status gizi anak prasekolah memiliki hubungan yang sangat signifikan dengan praktek sanitasi. Hal tersebut menunjukkan bahwa anakanak yang memiliki praktek sanitasi yang baik juga memiliki status gizi normal. Keadaan sanitasi lingkungan yang buruk akan berdampak pada kesehatan balita yang sebagian besar mengarah pada kejadian stunting. Badan Kesehatan Dunia, WHO, mengkategorikan angka stunting 20\% sampai dengan kurang dari 30\% sebagai tinggi, dan lebih dari atau sama dengan 30\% sangat tinggi. WHO juga mencatat 60 dari 134 negara masih memiliki tingkat stunting di bawah standar 20\%. Padahal stunting merupakan indikator kunci kesejahteraan anak secara keseluruhan. Sebuah hasil penelitian yang dilakukan oleh Rahayu dan Darmawan (2019) menunjukkan sebuah keterkaitan antara sanitasi lingkungan dengan kejadian stunting pada balita. Hasil penelitian tersebut menunjukkan bahwa balita dengan status gizi normal sebagian besar memiliki sanitasi lingkungan dengan kategori baik yaitu $100 \%$. Balita dengan status gizi stunting sebagian besar memiliki sanitasi lingkungan dengan kategorri baik yaitu sebesar $68,4 \%$, namun balita dengan status gizi stunting sebesar $31,6 \%$ memiliki sanitasi lingkungan dengan kategori tidak baik. Sehingga disimpulkan bahwa ada hubungan yang signifikan antara sanitasi lingkungan tidak baik dengan kejadian stunting pada balita. Hasil tersebut sejalan dengan pengamatan yang dilakukan di Desa Jenggala.

Tabel 1. Kondisi Gizi Anak (Puskesmas Kecamatan Tanjung, 2019)

\begin{tabular}{|c|c|c|c|}
\hline $\begin{array}{c}\text { Kondisi } \\
\text { Gizi }\end{array}$ & $\begin{array}{l}\text { Tinggi } \\
\text { Badan }\end{array}$ & $\begin{array}{l}\text { Berat } \\
\text { Badan }\end{array}$ & $\begin{array}{c}\text { Jumlah } \\
\text { Anak }\end{array}$ \\
\hline \multirow[t]{4}{*}{ Gizi baik } & Pendek & Normal & 113 \\
\hline & $\begin{array}{l}\text { Sangat } \\
\text { pendek }\end{array}$ & Gemuk & 6 \\
\hline & Pendek & Gemuk & 24 \\
\hline & $\begin{array}{l}\text { Sangat } \\
\text { pendek }\end{array}$ & Normal & 12 \\
\hline \multirow{3}{*}{$\begin{array}{c}\text { Gizi } \\
\text { kurang }\end{array}$} & Pendek & Normal & 21 \\
\hline & $\begin{array}{l}\text { Sangat } \\
\text { pendek }\end{array}$ & Normal & 9 \\
\hline & Pendek & Kurus & 2 \\
\hline Gizi lebih & Pendek & Gemuk & 2 \\
\hline \multirow[t]{3}{*}{ Gizi buruk } & Pendek & Kurus & 2 \\
\hline & $\begin{array}{l}\text { Sangat } \\
\text { pendek }\end{array}$ & Kurus & 1 \\
\hline & Pendek & Kurus & 1 \\
\hline
\end{tabular}

Total jumlah anak-

anak 193

Kegiatan Penyuluhan dan Praktik Kebersihan

Berdasarkan hal tersebut, perlu adanya sebuah kegiatan penanggulangan kembali terhadap masalah stunting pada daerah tersebut dengan penyuluhan ataupun pelatihan untuk menekan kembali angka stunting pada daerah melalui pengetahuan. Selain itu, perlu adanya perbaikan terhadap fasilitas sanitasi masyarakat yang terdapat pada beberapa lokasi di Desa Jenggala, perbaikan akses kesehatan bagi masyarakat yang tinggal jauh dari sarana kesehatan yang tersedia, melengkapi fasilitas MCK bagi penderita stunting, sarana pembuangan sampah dan perbaikan infrastruktur jalan untuk kemudahan dalam mobilisasi. 
Dalam kegiatan ini, penekanan terhadap angka stunting di Desa Jenggala dilakukan melalui kegiatan sosialisasi Pola Hidup Bersih Dan Sehat (PHBS) yang dilaksanakan selama dua kali dengan sasaran yang berbeda seperti terlihat pada Gambar 4 dan 5. Sosialisasi pertama dilakukan dengan sasaran orang tua khususnya ibu-ibu PKK melalui pengarahan tentang PHBS dan diskusi terkait permasalahan dan solusi.

Sasaran berikutnya adalah sosialisasi dilaksanakan pada hari berbeda di SDN 2 Jenggala dengan sasaran anak usia sekolah yang bertujuan untuk memberikan pengetahuan bagaimana menjalankan PHBS dengan benar, serta memberikan praktek secara langsung tentang bagaimana mencuci tangan yang baik dan benar berdasarkan 6 langkah yang direkomendasikan oleh WHO dengan tujuan mengurangi resiko terjangkit penyakit yang rentan pada anak usia sekolah. Dalam menciptakan lingkungan yang sehat bagi kehidupan manusia, perlu adanya nilainilai yang dibangun sejak kecil untuk menciptakan kesadaran masyarakat yaitu dengan mulai melakukan hal-hal yang kecil seperti menerapkan kebiasaan buang sampah pada tempatnya, membersihkan jamban secara teratur, mencuci tangan dengan benar dan membersihkan lingkungan sekitar.

Hasil evaluasi menunjukkan sekitar $87 \%$ para Ibu dapat menjawab pertanyaan dan diskusi yang diberikan. Hal menunjukkan kemampuan mereka dalam menyerap materi yang bagus. Dengan demikian diharapkan Ibu-ibu PKK mampu menyebarkan materi ke teman ataupun keluarga. Sebaliknya, hampir seluruh anak-anak sekolah peserta sosialisasi tidak mengetahui cara mencucui tangan yang benar. Namun, setelah sosialisasi sekitar $80 \%$ siswa dapat melakukannya dengan baik dan benar.

Kegiatan sosialisasi dan praktek ini diharapkan dapat memberikan dampat positif kepada warga Desa Jenggala dengan cara:

1. Meningkatkan partisipasi masyarakat dalam proses perubahan lingkungan yang lebih baik lagi

2. Memberikan pemahaman serta pengetahuan kepada masyarakat akan pentingnya PHBS

3. Menekan kembali angka stunting di daerah tersebut melalui pemberian kesadaran dalam hal sanitasi

4. Mengoptimalkan tumbuh kembah anak dengan menghindarkan mereka dari penyakit akibat lingkungan yang kotor

5. Melalui ibu-ibu PKK dan anak-anak peserta kegiatan dapat menyebarkan materi ke teman ataupun keluarga di lingkungan Desa Jenggala.

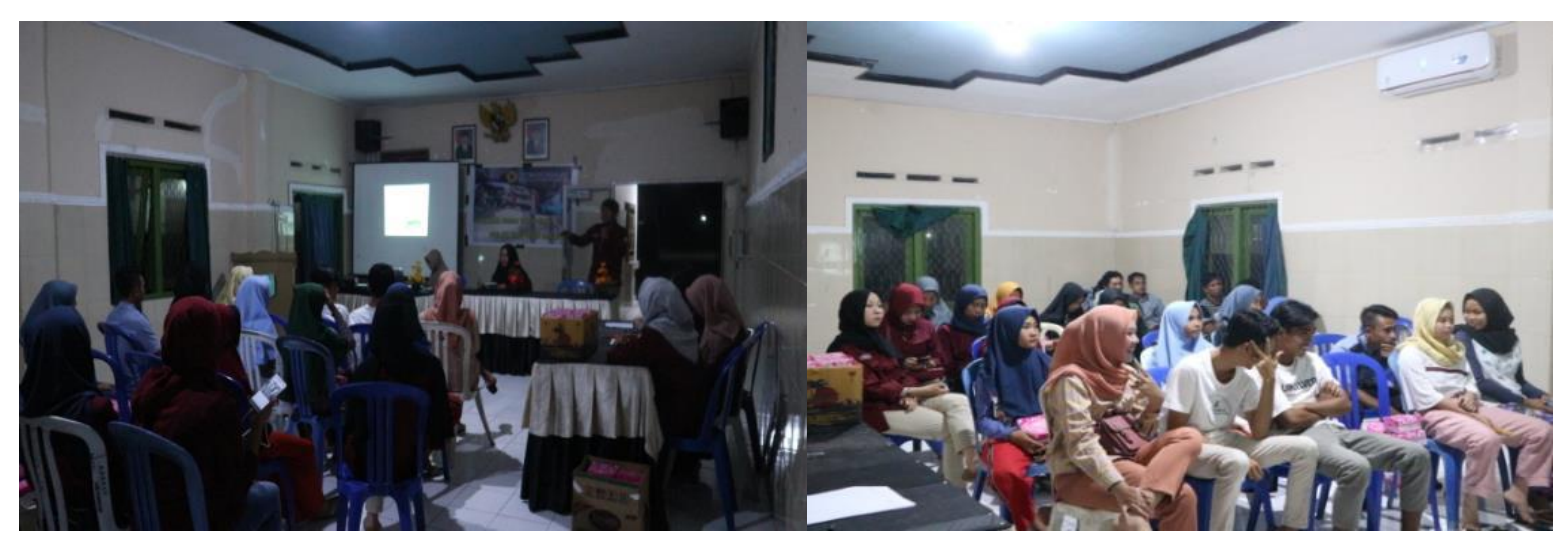

Gambar 4. Sosilisasi pada Ibu-ibu PKK 


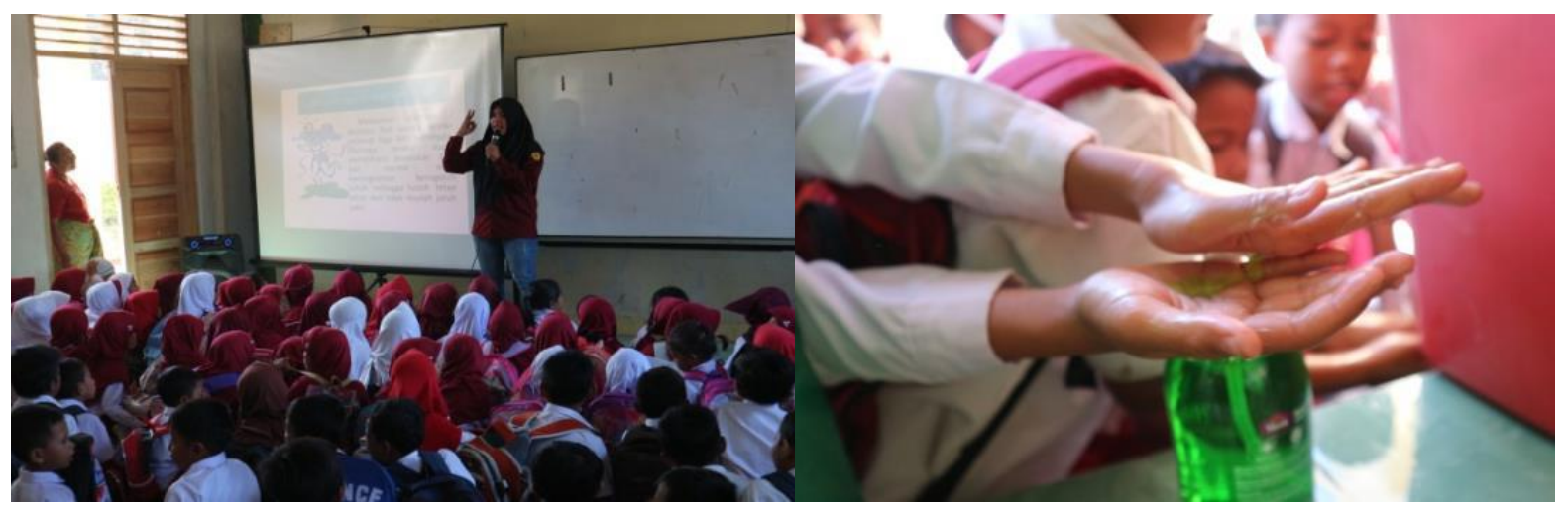

Gambar 5. Sosialisasi dan Praktek PHBS pada Anak-anak

\section{KESIMPULAN DAN SARAN}

\section{Kesimpulan}

Berdasarkan hasil observasi diperoleh bahwa secara umum di beberapa tempat di Desa Jenggala terdapat wilayah dengan sanitasi lingkungan yang kurang baik. Hal ini diasumsikan berkaitan dengan angka stunting desa Jenggala dimana sebanyak 38 anak dengan kategori stunting (gizi buruk). Penyerapan materi sosialisasi berhasil dengan baik karena hasil evaluasi menunjukkan sekitar $87 \%$ para lbu dapat menjawab pertanyaan serta sekitar $80 \%$ siswa sekolah dasar dapat melakukan praktek cara mencuci tangan dengan baik. Dengan demikian diharapkan Ibu-ibu PKK dan anak-anak sekolah mampu menyebarkan materi kepada keluarga masing-masing di rumah dan teman-teman di luar sekolah. Sosialisasi peningkatan kebersihan sanitasi lingkungan diharapkan mampu menekan angka stunting di Desa Jenggala di masa mendatang.

\section{Saran}

Pemerintah daerah sebaiknya melakukan kegiatan penyuluhan dan pelatihan yang berkaitan kesehatan lingkungan secara berkala, serta perlu dilakukan perbaikan fisik terhadap fasilitas sanitasi masyarakat, penyediaan fasilitas MCK bagi penderita stunting, dan penyediaan tempat penampungan sampah di masing-masing lingkungan.

\section{DAFTAR PUSTAKA}

Dinas Kesehatan Provinsi NTB, 2017, Profil Kesehatan Provinsi Nusa Tenggara Barat Tahun 2017, available: https://www.kemkes.go.id/resources/ download/profil/PROFIL_KES_PROVINS I_2017/ 18_NTB_2017.pdf

Fewtrell L and Colford JM Jr, 2005, Water, Sanitation and Hygiene in Developing Countries: Interventions and Diarrhoea-A Review, Water Sci Technol. 2005;52(12):299

Kementerian Kesehatan. 2018. Bersama Selesaikan Masalah Kesehatan, available:

http://www.Depkes.Go.Id/Article/View /18012900004/Together-OvercomingHealth-Problem-Html

Ningsih Indar DW, 2013, Hubungan Kesehatan Lingkungan Terhadap Status Gizi Anak Prasekolah Di Kelurahan Semanggi Dan Sangkrah Kecamatan Pasar Kliwon Surakarta, Laporan Penelitian Fakultas Ilmu Kesehatan, Universitas Muhammadiyah Surakarta.

Notoadmojo, 2003. Sanitasi Lingkungan, Direktori File Universitas Pendidikan Indonesia, available: https://studylibid.com/doc/1078580/s anitasi-lingkungan---direktori-file-upi.

Prastiti L dan Sofyan R, 2019, Penyuluhan Sanitasi Higiene Dan Phbs Pada Masyarakat Kawasan Candi Batujaya, Sebagai Dasar Membangun Desa Wisata Yang Bersih Dan Sehat, JPKM 
(Jurnal Pengabdian Kepada Masyarakat, Vol 1 No 01 (2019): Vol 1 No 01

Rahayu B dan Darmawan S, 2019, Hubungan Karakteristik Balita, Orang Tua, Higiene, Dan Sanitasi Lingkungan Terhadap Stunting Pada Balita, Binawan Student Journal, No: 1. Vol: 1. Hal: 23.

Ruel MT and Arimond M, 2003, Measuring Chilcare Practices, International Food Policy Research Institute, Washington

United National Children Foundation (UNICEF). 2012. Prevalensi Balita Stunting Di Indonesia. Http://www. Unicef.Org .

Vilcins, D., Sly, P.D., and Jagals, P., Environmental Risk Factors Associated with Child Stunting: A Systematic Review of the Literature, Ann Glob Health. 2018; 84(4): 551-562.Published online 2018 Nov 5. doi: 10.29024/aogh.2361

Waluya, B, (2008), Sanitasi Lingkungan, Direktori File Universitas Pendidikan Indonesia

World Health Organization. 2014. Global Nutrion Targets 2025 Stunting Policy Brief. Geneva Swetzwrland: World Health

Organization. Http://www.who.int. 